\title{
Isolation and screening of nitrogen fixing endophytic bacterium Gluconacetobacter diazotrophicus GdS25
}

\author{
Hema C. Rao* and V.P. Savalgi \\ Department of Agricultural Microbiology, University of Agricultural Sciences, \\ Dharwad - 580005, Karnataka, India \\ *Corresponding author
}

\begin{abstract}
A B S T R A C T
Keywords

Gluconacetobacter diazotrophicus, Nitrogen fixing ability,

Phytohormones, Phosphorus and Zinc solubilization.

Article Info

Accepted:

20 February 2017

Available Online:

10 March 2017

The present study is on the isolation, characterization and screening of endophytic bacterium i.e., Gluconacetobacter diazotrophicus which was isolated from the tissues of surface sterilized roots of four different crops viz., sugarcane, maize, pineapple and carrot. The morphological and biochemical tests permitted characterization of Gluconacetobacter diazotrophicus isolates. Further the plant growth promoting traits such as nitrogen fixing ability, production of phytohormones (Indole acetic acid and Gibberellic acid), phosphorus and zinc solubilization and antagonistic activity by dual culture method were assessed. Out of 113 isolated screened only 10 efficient isolates from various crops were selected based on nitrogen fixing capacity. An isolate from sugarcane GdS25 fixed maximum nitrogen i.e., $147 \mu \mathrm{g}$ of $\mathrm{N} / \mathrm{mg}$ of Carbon used and produced maximum concentration of Indole acetic acid $(4.94 \mu \mathrm{g} / \mathrm{ml})$ and Gibberellic acid $(7.1 \mu \mathrm{g} / 25 \mathrm{ml})$ respectively. GdS25 showed phosphorus solubilization zone of hydrolosis $2.1 \mathrm{~cm}$ where as zone of zinc solubilisation of $3.5 \mathrm{~cm}$. An isolate from sugarcane GdS25 exhibited 83\% inhibition against Rhizoctonia bataticola and $88 \%$ against Exerohilium maydis. The GdS25 is more potent as compared to the reference strain G. diazotrophicus MTCC1224.Five efficient isolates viz., GdS25, GdS26, GdM5, GdM6 and GdP7 will be taken up for further studies.
\end{abstract}

\section{Introduction}

Gluconacetobacter diazotrophicus is an endophytic bacterium first isolated from the sugarcane growing regions of Brazil (Cavalcante and Dobereiner, 1988). It was widely studied and used as a model system to assess the bacterial endophyte - plant interactions. After its first discovery, it was reported from variety of crops viz., coffee (Jimenez-Salgado et al., 1997), ragi (Loganathan et al., 1999), pineapple (Hernandez et al., 2000) and a latest report states Gluconacetobacter $s p$. as a natural colonizer of the wild rice (Porteresia coarctata Tateoka, formerly Oryza coarctata Roxb.) and a salt tolerant Pokali rice variety (Loganathan and Nair, 2003). These reports clearly indicated the wide occurrence of $G$. diazotrophicus in different plants than initially expected.

The endophytic nitrogen fixation concept has been recently gaining momentum. The biologically fixed nitrogen can supplement the nitrogen requirement of the crops in case of $\mathrm{N}$ deficit soils. Another important trait beneficial to the plant health is the production 
of growth hormones. G. diazotrophicus has the ability to produce both auxins and gibberellins in significant quantities (Bastian et al., 1998).

Now-a-days, screening organism for the phosphorus solubilizing ability is also considered as an agronomically important trait for an endophytic bacterial isolate (Suman et al., 2001; Verma et al., 2001).

Apart from phosphorus, micronutrients like $\mathrm{Zn}, \mathrm{Fe}$ and $\mathrm{Mn}$ were found to be deficient in most of the soils with $\mathrm{Zn}$ as a foremost nutrient throughout the world (Alloway, 2001). The soluble form of $\mathrm{Zn}$ applied to the soil gets transformed into different unavailable forms due to soil reaction.

Thus if an isolate has the ability to solubilize this insoluble form to soluble one, it will contribute significantly to the crop productivity. G. diazotrophicus exhibits antagonistic property against many bacterial and fungal pathogens. It has also been established that $G$. diazotrophicus exhibits antagonistic potential against Colletrotrichum falcatum, a causal organism of redrot in sugarcane (Mutthukumarsamy et al., 2002).

The recent findings state that properties other than nitrogen fixation like production of growth promoting substances, increased nutrient uptake, synthesis of plant growth modulation enzymes like ACC deaminase, enhanced stress resistance are the key factors for plant growth promotion of a diazotroph in the rhizosphere region (Dobbelaere et al., 2003). So a study was carried out with the aim to isolate Gluconacetobacter diazotrophicus from various crops, characterize them and further the growth promoting parameters like nitrogen fixing ability, growth hormone production, antagonistic activity, phosphorus and zinc solubilization were also assessed to screen the efficient strains to take them to pot culture experiment.

\section{Materials and Methods}

\section{Locations of the sampling sites}

The root samples of sugarcane, maize, pineapple and carrot were collected from Dharwad, Belgaum, Uttara Kannada and Shimoga districts of Karnataka, India. Dharwad district is situated in the western sector of the northern half of Karnataka which encompasses an area of $4263 \mathrm{~km}^{2}$ lying between the latitudinal parallels of $15^{\circ} 02^{\prime}$ and $15^{\circ} 51^{\prime}$ North and longitudes of $73^{\circ} 43^{\prime}$ and $75^{\circ} 35^{\prime}$ East. The district is bounded on the north by the district of Belgaum, on the east by the district of Gadag, on the south Haveri and on the west by Uttara Kannada. Shimoga lies between the latitudes $13^{\circ} 27^{\prime}$ and $14^{\circ} 39^{\prime} \mathrm{N}$ and between the longitudes $74^{\circ} 38^{\prime}$ and $76^{\circ} 04^{\prime}$ $E$ at a mean altitude of 640 metres above sea level and spread over an area of $8465 \mathrm{~km}^{2}$.

\section{Media and cultural conditions}

$\mathrm{N}$-free semisolid LGI medium supplemented with $0.5 \%$ sugarcane juice at $\mathrm{pH} 4.5$ was used (Cavalcante and Dobereiner, 1988). For isolation and culturing, acetic acid LGI agar plates supplemented with yeast extract $(50 \mathrm{mg}$ /1) and potato agar plates with $10 \%$ cane sugar were used (Cavalcante and Dobereiner, 1988).

\section{Preparation of root samples}

Since G.diazotrophicus is an endophyte, the isolation was done using root samples. The plants were uprooted and the root portion was separated and washed with tap water. The roots were washed with sterile distilled water and surface sterilized for 5 min with $5 \%$ sodium hypochlorite $(\mathrm{NaOCl})$, and then washed five times with sterile distilled water. 


\section{Isolation of $G$. diazotrophicus}

The surface sterilized root samples were weighed and homogenized in a sterile sucrose solution (1\%) using a sterile pestle and mortar. Aliquots $(500 \mathrm{ml})$ were inoculated in semisolid LGI (Cavalcante and Dobereiner, 1988) and incubated at $30^{\circ} \mathrm{C}$ for $4-6$ days. Fifteen replicates from each plant part (root, stem, leaf, and rhizosphere) were inoculated in semisolid LGI tubes. Yellowish bacterial growth from the tubes was streaked onto LGI plates (Cavalcante and Dobereiner, 1988) and incubated at $30^{\circ} \mathrm{C}$ for $6-7$ days. The colony morphology was compared with reference strain G. diazotrophicus (MTCC culture 1224).

\section{Biochemical characterization of isolates}

The isolates presumably identified as $G$. diazotrophicus using LGI media were further characterized using a series of biochemical tests viz., Gram stain, motility, catalase, gelatin hydrolysis, over-oxidation of ethanol, brown pigment production on GYC agar, growth on carbon sources, growth at various concentrations of sugar and growth at various temperatures, according to Dong et al., (1995) and Muthukumarasamy et al., (1999).

\section{Evaluation of plant growth promoting activities}

\section{Nitrogen fixing ability: nitrogen estimation} by microkjeldhal method

The 48 hour old cultures were inoculated to $5 \mathrm{ml}$ of $\mathrm{N}$ free semi solid broth of LGI medium. It was incubated for 48 hours. $1 \mathrm{ml}$ of this broth was inoculated to $50 \mathrm{ml}$ semisolid medium. Then it was incubated for 15 days. $10 \mathrm{ml}$ of this culture was used for $\mathrm{N}$ estimation by following the standard procedure of Microkjeldhal technique (Reis et al., 1994). The formula for $\mathrm{N}_{2}$ estimation is:
$\mathrm{N}_{2}(\mathrm{mg} / \mathrm{g})=\mathrm{ml}$ of $\mathrm{H}_{2} \mathrm{SO}_{4}$ in the sample $\mathrm{x}$ Normality of $\mathrm{H}_{2} \mathrm{SO}_{4} \times 14.01$ / Weight of the sample (Carbon used in grams)

\section{Estimation of phytohormones: IAA and GA}

The flasks containing $50 \mathrm{ml}$ Czapeck's solution was prepared and autoclaved. Inoculate the flasks with $500 \mu \mathrm{l}$ of $72 \mathrm{~h}$ old culture of each isolate. Incubate at $30^{\circ} \mathrm{C}$ for 7 days. The cultures were spinned at $3300 \mathrm{x} \mathrm{g}$ for 20 minutes. The supernatant was used for the estimation of IAA and GA. Quantitative estimation of IAA was done by Spectrophotometer method (Ivanova et al., 2001) and GA was estimated by the method stated by Bastian et al., 1998.

\section{Phosphorus and zinc solubilization}

To assess the phosphorus and zinc solubilization potential, both plate and broth assays were performed in LGI medium (Cavalcante and Dobereiner, 1988). For plate assay glucose was chosen as carbon sources at $1 \%$ concentration and medium was supplemented with insoluble zinc compounds viz., zinc oxide $(\mathrm{ZnO})$, zinc carbonate $(\mathrm{ZnCO} 3)$ and zinc phosphate $(\mathrm{ZnPO} 4)$ as separate treatments at $0.1 \%$ concentrations. The insoluble nutrient compounds supplemented media were added to sterile Petriplates. After solidification, $48 \mathrm{~h}$ old $\left(6 \times 10^{8} \mathrm{CFU} \mathrm{mL}^{-1}\right)$ cultures of $G$. diazotrophicus strains at $10 \mu 1$ concentration was placed over the media and incubated at $28^{\circ} \mathrm{C}$ for 3 days. After incubation, the diameter of the zone of solubilization was measured in $\mathrm{cm}$. The amount of solubilization was assessed as per procedure given by Fasim et al., (2002).

Antagonistic activity: Dual culture assay (Dennis and Webster, 1971) 
Pathogens used:

1. Rhizoctonia bataticola - Charcoal rot

2. Exserohilum maydis - Tursicum leaf blight

The dual culture assay was done. PDA (Potato dextrose agar) was used. $5 \mathrm{~mm}$ of mycelial disc of the pathogen was placed at the center. A loopful of the bacteria was streaked $3 \mathrm{~cm}$ away from the pathogen on both sides and incubated at $30^{\circ} \mathrm{C}$ for 7 days. Petri plates inoculated with only pathogen served as control. The growth was measured using scale in centimeters.

The $\%$ growth inhibition (PGI) was calculated using the formula

PGI $\%=\mathrm{C}-\mathrm{T} / \mathrm{C} \mathrm{X} 100$

$\mathrm{C}-$ growth in the control plate $\mathrm{T}-$ growth in the test plate

\section{Results and Discussion}

\section{Isolation, identification and biochemical characterization of endophytic bacterial isolates}

Presumptive strains of G. diazotrophicus were assessed in the plant samples collected from various parts of Dharwad, Belgaum, Uttar Kannada and Shimoga districts of Karnataka state in India. For preliminary screening, the cultures were isolated using LGI, a medium used for $G$. diazotrophicus isolation (Cavalcante and Dobereiner, 1988).

The formation of orange colour colony on LGI media was taken as prime criterion to identify the G. diazotrophicus isolates (Fig. 1) .Based on this property a total of 113 strains were identified from four crops (Table 1). 50 isolates of G. diazotrophicus from sugarcane, 21 from Maize, 19 from Carrot and 23 from Pineapple roots were isolated. These isolates were further characterized biochemically for specific characters of $G$. diazotrophicus according to Burgey's Manual of Systematic Bacteriology (Table 2). All the isolates were positive for most of characters specific for $G$. diazotrophicus. Further all isolates tested negative for the biochemical character like gelatin hydrolysis.

\section{Plant growth promoting traits}

The cultures were assessed for the plant growth promoting traits, such as nitrogen fixation ability, phytohormone production, phosphorus and zinc solubilization.

\section{Nitrogen fixation ability (Microkjeldhal method)}

All the 113 isolates were subjected to know the nitrogen fixation by Microkjeldhal method. 34 isolates efficiently fixed considerable amount of nitrogen. Among them ten best isolates were selected for further characterization.

An isolate from Maize GdM5fixed about 42 $\mu \mathrm{g}$ of Nitrogen/ $\mathrm{mg}$ of Carbon used which is equivalent to that of reference culture of $G$. diazotrophicus (MTCC1224). Whereas the isolate from sugarcane GdS25 fixed highest amount of nitrogen than other strains i.e., 147 $\mu \mathrm{g}$ of $\mathrm{N} / \mathrm{mg}$ of $\mathrm{C}$ used. A strain from Pineapple GdP7 fixed about $49 \mu \mathrm{g}$ of $\mathrm{N} / \mathrm{mg}$ of C. An isolate from carrot recorded lowest value of $28 \mu \mathrm{g}$ of $\mathrm{N} / \mathrm{mg}$ of C (Table3).

\section{Phytohormone production}

IAA producing ability differed among the isolates. All the ten strains produced IAA. The highest IAA was produced by an isolate from sugarcane GdS25 i.e., $4.94 \mu \mathrm{g} / \mathrm{ml}$. An isolate from carrot produced lowest IAA i.e., $3.09 \mu \mathrm{g} / \mathrm{ml}$. The same trend was observed for GA production (Table 4). 
Table.1 Isolates of Gluconacetobacter diazotrophicus from various crops

\begin{tabular}{|l|c|c|}
\hline Name of the crop & Isolate recovered from & Number of isolates \\
\hline Sugarcane & Root tissue & 50 \\
\hline Maize & Root tissue & 21 \\
\hline Pineapple & Root tissue & 23 \\
\hline Carrot & Root tissue & 19 \\
\hline
\end{tabular}

Table.2 Selective biochemical tests of Gluconacetobacter diazotrophicus isolates

\begin{tabular}{|c|c|c|c|c|}
\hline Particulars & \multicolumn{4}{|c|}{ Gluconacetobacter diazotrophicus isolates } \\
\hline Crops & Sugarcane & Maize & Pineapple & Carrot \\
\hline Cell Shape & Rod shaped & Rod shaped & Rod shaped & Rod shaped \\
\hline Gram reaction & Gram negative & Gram negative & Gram negative & Gram negative \\
\hline Motility & + & + & + & + \\
\hline $\begin{array}{l}\text { Brown pigment } \\
\text { on GYC medium }\end{array}$ & + & + & + & + \\
\hline $\begin{array}{l}\text { Gelatin } \\
\text { liquefaction }\end{array}$ & - & - & - & - \\
\hline Catalase activity & + & + & + & + \\
\hline $\begin{array}{l}\text { Oxidation of } \\
\text { ethanol }\end{array}$ & + & + & + & + \\
\hline $\begin{array}{l}\text { Growth on C } \\
\text { sources } \\
\text { Glucose } \\
\text { Sucrose } \\
\text { Ethanol } \\
\text { Mannitol } \\
\end{array}$ & $\begin{array}{l}+ \\
+ \\
+ \\
+\end{array}$ & $\begin{array}{l}+ \\
+ \\
+ \\
+\end{array}$ & $\begin{array}{l}+ \\
+ \\
+ \\
+\end{array}$ & $\begin{array}{l}+ \\
+ \\
+ \\
+\end{array}$ \\
\hline $\begin{array}{l}\text { Growth at } \\
\text { various } \\
\text { concentration of } \\
\text { sugar } \\
5 \% \\
10 \% \\
20 \% \\
30 \% \\
\end{array}$ & $\begin{array}{l}+ \\
+ \\
+ \\
+\end{array}$ & $\begin{array}{l}+ \\
+ \\
+ \\
+\end{array}$ & $\begin{array}{l}+ \\
+ \\
+ \\
+\end{array}$ & $\begin{array}{l}+ \\
+ \\
+ \\
+\end{array}$ \\
\hline $\begin{array}{l}\text { Growth at } \\
\text { various } \\
\text { temperatures } \\
4^{\circ} \mathrm{C} \\
28^{\circ} \mathrm{C} \\
32^{\circ} \mathrm{C} \\
37^{\circ} \mathrm{C}\end{array}$ & $\begin{array}{l}- \\
+ \\
+ \\
+\end{array}$ & $\begin{array}{l}- \\
+ \\
+ \\
+\end{array}$ & $\begin{array}{l}- \\
+ \\
+ \\
+\end{array}$ & $\begin{array}{l}- \\
+ \\
+ \\
+\end{array}$ \\
\hline
\end{tabular}


Table.3 Nitrogen fixation ability of Gluconacetobacter diazotrophicus isolates by Microkjeldhal method

\begin{tabular}{|c|c|c|}
\hline SI. No. & Isolate Code & $\mu \mathrm{g}$ of Nitrogen/ mg of Carbon \\
\hline 1 & GdS25 & 147.10 \\
\hline 2 & GdS26 & 140.10 \\
\hline 3 & GdS6 & 91.06 \\
\hline 4 & GdS13 & 91.06 \\
\hline 5 & GdS24 & 84.06 \\
\hline 6 & GdS27 & 63.04 \\
\hline 7 & GdM5 & 42.03 \\
\hline 8 & GdM6 & 35.02 \\
\hline 9 & GdP7 & 49.03 \\
\hline 10 & GdC16 & 28.02 \\
\hline 11 & $\begin{array}{l}\text { Reference strain of G. diazotrophicus } \\
\text { MTCC1224 }\end{array}$ \\
\hline
\end{tabular}

Table.4 The production of IAA, GA production, phosphorus and zinc solubilization zone by the selected efficient strains of Gluconacetobacter diazotrophicus

\begin{tabular}{|c|c|c|c|c|c|}
\hline SI.No. & Isolate Code & $\begin{array}{c}\text { IAA } \\
(\mu \mathrm{g} / \mathrm{ml})\end{array}$ & $\begin{array}{l}\text { GA }(\mu \mathrm{g} / \\
25 \mathrm{ml})\end{array}$ & $\begin{array}{c}\text { P solubilization } \\
\text { zone } \\
(\mathrm{cm})\end{array}$ & $\begin{array}{l}\text { Zn solubilization } \\
\text { zone } \\
(\mathrm{cm})\end{array}$ \\
\hline 1 & GdS6 & 4.63 & 5.75 & 1.8 & 2.8 \\
\hline 2 & GdS13 & 4.54 & 5.36 & 1.7 & 2.7 \\
\hline 3 & GdS24 & 3.96 & 5.18 & 1.5 & 2.2 \\
\hline 4 & GdS25 & 4.94 & 7.10 & 2.1 & 3.5 \\
\hline 5 & GdS26 & 4.78 & 6.95 & 2.0 & 3.1 \\
\hline 6 & GdS27 & 3.80 & 5.10 & 1.3 & 2.0 \\
\hline 7 & GdM5 & 3.42 & 4.54 & 1.4 & 2.6 \\
\hline 8 & GdM6 & 3.15 & 4.09 & 1.5 & 2.5 \\
\hline 9 & GdC16 & 3.09 & 3.09 & 1.1 & 1.5 \\
\hline 10 & GdP7 & 3.58 & 4.97 & 1.7 & 2.7 \\
\hline 11 & $\begin{array}{l}\text { Reference strain of } \\
\text { G. diazotrophicus }\end{array}$ & 4.50 & 6.50 & 2.0 & 3.0 \\
\hline
\end{tabular}


Table.5 The antagonistic activity of the selected efficient strains of Gluconacetobacter diazotrophicus

\begin{tabular}{|c|c|c|c|}
\hline SI.No. & Isolate Code & $\begin{array}{c}\text { Per cent inhibition (\%) } \\
\text { (Rhizoctonia } \\
\text { bataticola) }\end{array}$ & $\begin{array}{c}\text { Per cent inhibition } \\
(\%) \\
\text { (Exserohilum maydis) }\end{array}$ \\
\hline 1 & GdS6 & 72.23 & 77.78 \\
\hline 2 & GdS13 & 75.56 & 75.56 \\
\hline 3 & GdS24 & 74.45 & 80.00 \\
\hline 4 & GdS25 & 83.33 & 88.89 \\
\hline 5 & GdS26 & 80.00 & 86.25 \\
\hline 6 & GdS27 & 70.30 & 74.31 \\
\hline 7 & GdM5 & 77.78 & 83.34 \\
\hline 8 & GdM6 & 76.27 & 81.33 \\
\hline 9 & GdC16 & 61.12 & 72.28 \\
\hline 10 & GdP7 & 75.28 & 76.23 \\
\hline 11 & Reference strain of & 79.80 & 85.50 \\
\hline
\end{tabular}

Figure.1 Colony morphologies of Gluconacetobacter diazotrophicus isolates A (GdS25), B (GdM5), C (GdP7) and D (GdC16) grown at $30^{\circ} \mathrm{C}$ for $72 \mathrm{~h}$ in LGI medium obtained from Sugarcane, Maize, Pineapple and Carrot, respectively

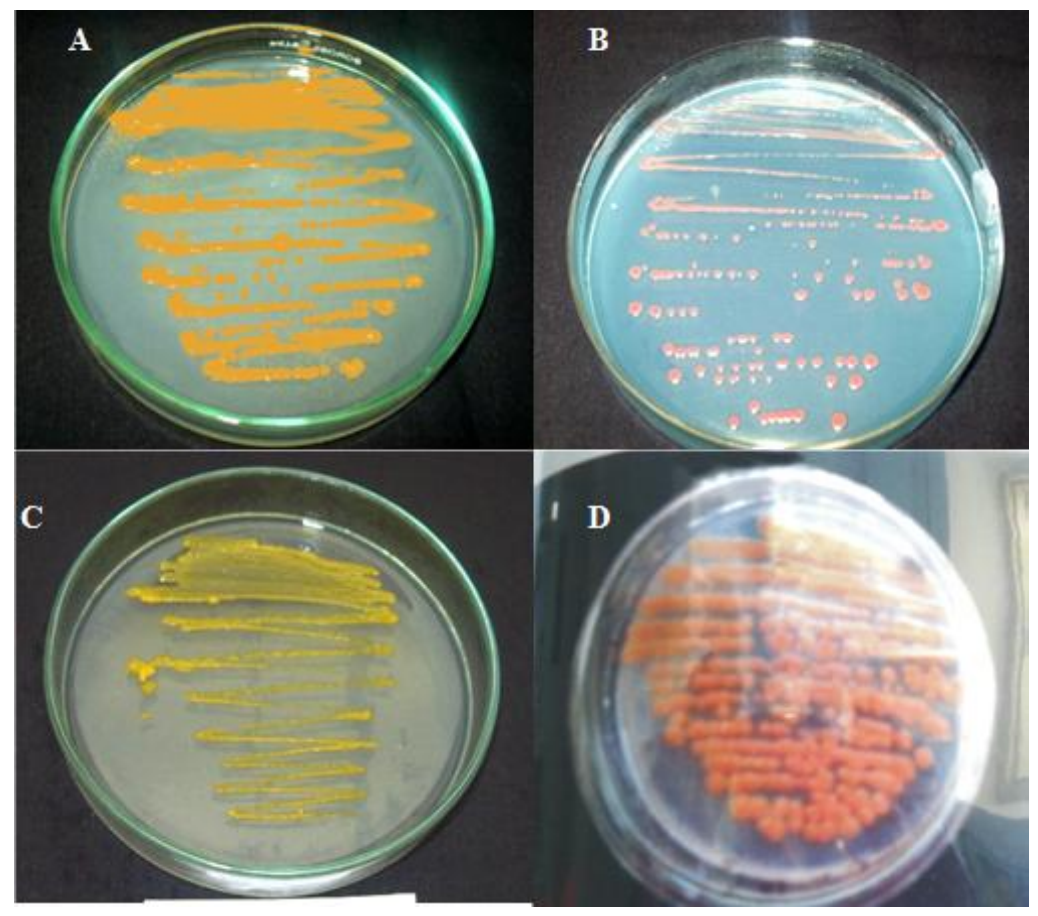




\section{Phosphorus and zinc solubilization ability}

All the ten isolates solubilized $\mathrm{P}$ and $\mathrm{Zn}$. The larger $\mathrm{P}$ solubilization zone was observed in case of sugarcane isolate $\mathrm{GdS} 25$ i.e., $2.1 \mathrm{~cm}$ and the lowest was in case of carrot isolate GdC16 i.e., $1.1 \mathrm{~cm}$.The same trend was observed for $\mathrm{Zn}$ solubilization ability (Table 4).

\section{Antagonistic activity}

The dual culture assay was carried out to find out the per cent inhibition. An isolate from sugarcane GdS25 exhibited 83\% inhibition against Rhizoctonia bataticola and 88\% against Exerohilium sp. The maize isolate GdM5 recorded $77 \%$ and $83 \%$ inhibition against both the pathogens respectively (Table 5).

\section{Screening of G. diazotrophicus isolates}

Out of 113 strains which were isolated from four different crops i.e., sugarcane, maize, pine apple and carrot, 5 efficient isolates viz., GdS25, GdS26, GdM5, GdM6 and GdP7 were screened based on the morphological and biochemical characterization and plant growth promoting traits.

Exploration of diazotrophs from different crops paves way to reduce the cost incurred on nitrogen fertilizers as well as minimizes the risk of pollution created by continuous application of fertilizers. Though $G$. diazotrophicus was first isolated from sugarcane (Cavalcante and Dobereiner, 1988), a further study in literature clearly showed its wide occurrence in different crops (JimenezSalgado et al., 1997; Loganathan et al., 1999; Hernandez et al., 2000). So, it is not astonishing to obtain 113 isolates of $G$. diazotrophicus from various crops like sugarcane, maize, pineapple and carrot. These plants contain in their cell sap considerable amount of sucrose so they can survive in the plant system and proliferate. The selective biochemical tests clearly points out the occurrence of G. diazotrophicus.

These putative endophytic strains of $G$. diazotrophicus also exhibited considerable amount of nitrogen fixation equivalent to that of the reference strain of G. diazotrophicus isolated from sugarcane environment. Among 113 isolates a strain from sugarcane (GdS25) fixed maximum amount of nitrogen and highest IAA production, indicating its possibility to be used as a bioinoculant. The endophytes are postulated to play an important role in sustainable crop production, probable mechanism of growth promotion may be by growth hormones. IAA and gibberellins have been found in the cultures of G. diazotrophicus (Bastian et al., 1998). Till date Azospirillum is the promising diazotroph recommended to graminaceous crops as biofertilizer.

All the isolates exhibited significant amount of phosphate solubilizing ability and zincsolubilizing ability. Inclusion of a bacteria solubilizing zinc, as a bioinoculant in crop production technology is really beneficial for a country like India having high incidence of zinc deficiency (more than 70\%) (Alloway, 2001).

Thus, understanding basic mechanisms behind the growth promotion may help to minimize the cost of crop production e.g. phosphorus and zinc are the nutrients that are essentially required by the crops but they are relatively leached from soil or transformed into insoluble/ sparingly soluble form by complex soil reactions and become totally unavailable to plants. Hence the combined use of $G$. diazotrophicus with cheaper materials like rock phosphate and zinc insoluble compounds/ores may help in alleviating the status of these nutrients. 
Apart from all these growth promotion activities, G. diazotrophicus strains have the additional property of biocontrol potential against soil borne pathogenic fungi and this should be explored in depth to exploit the complete potential of $G$. diazotrophicus as one of the biocontrol agents (Logeshwaran et al., 2011).

Based on morphological, biochemical and functional characterization, it is concluded that GdS25, GdS26 isolated from sugarcane, GdM5 , GdM6 isolated from maize and GdP7 isolated from pineapple proved to be more potent isolates and will be taken for further pot and field trials. These isolates can be exploited in future as biofertilizers for the improvement of crop productivity and as biocontrol agent against plant pathogenic fungi. The coming years are going to witness the new dimensions of plant growth promotion by Gluconacetobacter diazotrophicus apart from its nitrogen fixing and growth hormone producing ability. Thus the studies on Gluconacetobacter diazotrophicus may be diversified, several basic growth promoting properties of these bacteria can be elucidated.

\section{Acknowledgement}

I am thankful to the Department of Agricultural Microbiology, University of Agricultural Sciences, Dharwad, Karnataka state, India for providing all the facilities to conduct my research work.

Conflict of interest: There is no conflict of interest.

\section{References}

Alloway, B.J. 2001. Zinc the vital micronutrient for healthy, high-value crops. International zinc association (pamphlet), Brussels, Belgium, pp. 1-7.
Bastian, F., Cohen, A., Piccoli, P., Luna, V., Baraldi, R. and Bottini, R. 1998. Production of indole-3-acetic acid and gibberellins A1 and A3 by Acetobacter diazotrophicus and Herbaspirillum seropedicae in chemically defined culture media. Pl. Growth Regul., 24: 7-11.

Cavalcante, V.A. and Dobereiner, J. 1988. A new acid tolerant nitrogen-fixing bacterium associated with sugarcane. Plant Soil, 108: 23-31.

Dennis, C. and Webster, J. 1971. Antagonistic properties of species groups of Trichoderma and production of non volatile antibiotics. Trans. Br. Mycol. Soc., 57: 25-39.

Dong, Z., Haydrich, M., Bernard, K. and McCully, M.E.1995. Further evidence that N2 fixing endophytic bacterium from the intercellular spaces of sugarcane stems is Acetobacter diazotrophicus. Appl. Environ. Microbiol., 61: 1843-1846.

Fasim, F., Ahmed, N., Parsons, R. and Gadd, G.M. 2002. Solubilization of zinc salts by a bacterium isolated from the air environment of a tannery. FEMS Microbiol. Lett., 213: 1-6.

Hernandez, A.T., Bustillos-Cristales, M.R., Jimenez-Salgado, T., CaballeroMellado, J. and Fuentez-Ramirez, L.E. 2000. Natural endophytic occurrence of Acetobacter diazotrophicus in pineapple plants. Microb. Ecol., 39: 49-55.

Ivanova, E.G., Doronina, N.V. and Trotsenko, Y.A., Aerobic methylobacteria are capable of synthesizing auxins. Microbiol., 70: 392-397.

Jimenez-Salgado, T., Fuentes-Ramirez, L.E., Tapia-Hernandez, A., Mascarua, M.A., Martinez-Romero, E. and CaballeroMellado, J., Coffea arabica L., a new host plant for Acetobacter diazotrophicus and isolation of other nitrogen fixing acetobacteria. Appl. 
Environ. Microbiol., 63: 3676-3683.

Loganathan, P., Sunitha, R., Parida, A.K. and Nair, S. 1999. Isolation and characterization of two genetically distant groups of Acetobacter diazotrophicus from a new host Eleusine coracana L. J. Appl. Microbiol., 87:167-172.

Loganathan, P., Sunitha, R., Parida, A.K., Nair, S. 1999. Isolation and characterization of two genetically distant groups of Acetobacter diazotrophicus from a new host Eleusine coracana L. J. Appl. Microbiol., 87: 167-172.

Logeshwaran, P., Thangaraju, M. and Rajasundari, K. 2011. In vitro suppression of soil borne pathogenic fungi and pyluteorin production by Gluconacetobacter diazotrophicus. J. Basic. Appl. Sci. Res., 1(3): 150-156.

Muthukumarasamy, R., Revathi, G., Loganathan, P. 1994. Effect of inorganic $\mathrm{N}$ on the population, in vitro colonization and morphology of Acetobacter diazotrophicus (Syn. Gluconacetobacter diazotrophicus). Pl. Soil., 243: 91-102.

Reis, V.M., Olivares, F.L. and Dobereiner, J. 1994. Improved methodology for isolation of Acetobacter diazotrophicus and confirmation of its endophytic habitat. World J. Microbiol. Biotechnol., 10: 101-104.

Suman, A., Shasany, A.K., Singh, M., Shahi, H.N., Gaur, A. and Khanuja, S.P.S. 2001. Molecular assessment of diversity among endophytic diazotrophs isolated from subtropical Indian sugarcane. World J. Microbiol. Biotechnol., 17: 39-45.

Verma, S.C., Ladha, J.K. and Tripathi, A.K. 2001. Evaluationof plant growth promoting and colonization ability of endophytic diazotrophs from deepwater rice. J. Biotechnol., 91: 127-141.

\section{How to cite this article:}

Hema C. Rao and Savalgi, V.P. 2017. Isolation and screening of nitrogen fixing endophytic bacterium Gluconacetobacter diazotrophicus GdS25. Int.J.Curr.Microbiol.App.Sci. 6(3): 13641373. doi: https://doi.org/10.20546/ijcmas.2017.603.158 